\title{
Sir John Suckling
}

$1609-42$

John Suckling was born in Middlesex into a wealthy Norfolk family; he was educated at Trinity College, Cambridge, and Gray's Inn. On the death of his father in 1628 he inherited large estates and assumed the life of a courtier; he was knighted in 1630 . He served as a Royalist soldier from 1639 to 1641 , and then fled to the Continent, where he died in mysterious circumstances, possibly by suicide. His literary works were collected posthumously. They include poems, songs, three plays, letters to various eminent figures, and an unorthodox religious tract.

\section{$\mathrm{SONG}^{\dagger}$}

Why so pale and wan, fond lover?

Prithee, ${ }^{\dagger}$ why so pale?

Will, when looking well can't move her,

Looking ill prevail?

5 Prithee, why so pale?

Why so dull and mute, young sinner?

Prithee, why so mute?

Will, when speaking well can't win her,

Saying nothing do't?

10 Prithee, why so mute?

Quit, quit, for shame, this will not move;

This cannot take her.

If of herself she will not love,

Nothing can make her.

15 The devil take her!

prithee colloquialism for 'I pray thee' 